\title{
INHIBITION OF CYTOTOXICITY BY INTRACELLULAR SUPEROXIDE DISMUTASE SUPPLEMENTATION
}

\author{
Barbara A. Markey, Sem H. Phan, James Varani, Una S. Ryan, * and Peter A. Ward \\ Department of Pathology, University of Michigan Medical School, Ann Arbor, MI 48109-0602, *Department of Medicine, \\ University of Miami School of Medicine, Miami, FL 33167
}

(Received 27 April 1990; Revised and Accepted 18 June 1990)

\begin{abstract}
The role of intracellular oxyradicals in $\mathrm{H}_{2} \mathrm{O}_{2}$ and neutrophil-induced cytotoxicity is suggested by previous studies showing protection by inhibitors such as deferroxamine, dimethylthiourea, and dimethyl sulfoxide. In the current studies, the role of intracellular $\mathrm{O}_{2}{ }^{-}$is specifically examined by evaluating the effects of intracellular superoxide dismutase (SOD) supplementation on cytotoxicity of rat pulmonary artery endothelial cells induced by $\mathrm{H}_{2} \mathrm{O}_{2}$ and activated neutrophils. To minimize in vitro manipulation, supplementation was accomplished by incubating endothelial cells in the presence of SOD $(1-20 \mathrm{mg} / \mathrm{mL})$. Increases up to $>17$-fold the baseline SOD activity were achievable using this approach, with uptake being maximal after $6 \mathrm{~h}$ of incubation. This increase was resistant to trypsin digestion, suggesting the intracellular location of SOD. Compared to controls, SOD-supplemented cells showed significantly increased resistance to killing by $\mathrm{H}_{2} \mathrm{O}_{2}$ and activated neutrophils. Inactive SOD failed to provide protection. The degree of protection was dependent on the dose of cytotoxic agent and the extent of SOD supplementation. The results provide new evidence that intracellular $\mathrm{O}_{2}{ }^{-}$participates in the killing process induced by these two stimuli. The intracellular source of $\mathrm{O}_{2}{ }^{-}$remains to be determined, although previous studies suggest xanthine oxidase as a likely candidate.
\end{abstract}

Keywords-Superoxide dismutase, Hydrogen peroxide, Neutrophils, Cytotoxicity, Endothelial cells, Free radicals

\section{INTRODUCTION}

The cellular injurious effects of oxidants from exogenous sources have been well documented. ${ }^{1}$ The production of endogenous intracellular oxidants and their role in cell injury in response to exogenous stimuli, however, have been less well characterized. Previous studies have shown the ability of endothelial cells to generate $\mathrm{O}_{2}{ }^{-}$and $\mathrm{H}_{2} \mathrm{O}_{2}{ }^{1,2}$ There is also suggestive evidence that these cells can be upregulated with respect to oxidant production in response to certain stimuli, which may contribute to the overall cytotoxicity of these stimuli. ${ }^{1}$ The importance of intracellular oxidants, whether they are from endogenous or exogenous sources, is suggested by results of studies using oxidant scavengers loaded into target cells prior to addition of exogenously derived oxidants. ${ }^{3-5}$

Loading of macromolecular oxidant scavengers into nonpermeabilized cells has been accomplished efficiently by encapsulating them in phospholipid vesicles and allowing them to fuse with cell membranes. Superoxide dismutase (SOD) and catalase have been introduced in

Address all correspondence to: Sem H. Phan, Department of Pathology, Box M0602, The University of Michigan Medical School, Ann Arbor, MI 48109-0602. this manner into cells in vitro and in vivo, and found to be effective in increasing resistance to oxidant-induced injury. ${ }^{3,4,6,7}$ Alternatively, modification of SOD and catalase with polyethylene glycol have been found effective in increasing uptake of these enzymes. ${ }^{4,5}$ Loading using these methods however, involves potentially injurious processes to the cell membrane, since alteration or abrogation of the permeability barrier of the cell may occur with the introduction of exogenous phospholipids or particulates. Phagocytosis of particulates is known to cause a number of functional responses in endothelial cells, including the increased generation of $\mathrm{O}_{2}{ }^{-}$and $\mathrm{H}_{2} \mathrm{O}_{2} \cdot{ }^{8}$ Polyethylene glycol also causes significant alteration in membrane fluidity. ${ }^{5}$ As an alternative and to minimize perturbation of the cells by the loading process, this study examined the efficacy of loading unmodified SOD into rat pulmonary artery endothelial cells by incubating them in the presence of increasing doses of this enzyme in normal media. Cells supplemented in this manner were then examined for their susceptibility to oxidant-induced injury in order to help determine if intracellular $\mathrm{O}_{2}{ }^{-}$plays a role in $\mathrm{H}_{2} \mathrm{O}_{2}$ and neutrophil-induced cell injury. Previous studies have confirmed the effectiveness of such supplementation in improving the cellular resistance to hyperoxia and xan- 

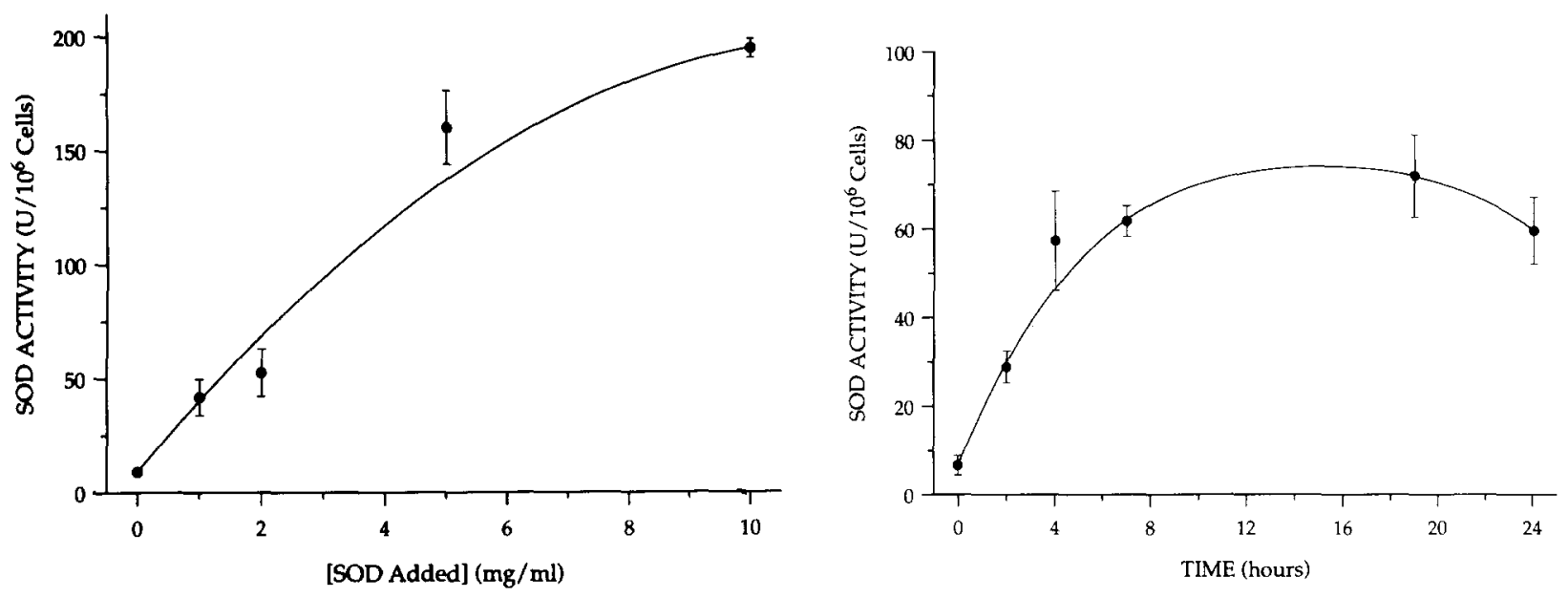

Fig. 1. Characterization of SOD loading. Dose response (A) and time course (B) of SOD loading are shown. For the dose-response curve (A) data, rat pulmonary artery endothelial cells were incubated with the indicated doses of SOD for $18 \mathrm{~h}$, and then washed, trypsinized, and extracted prior to assay for SOD activity as described in Methods. Data represent means $\pm \mathrm{SE}$ from four separate experiments. For the time course study (B), cells were incubated with $10 \mathrm{mg} / \mathrm{mL}$ of SOD for the times indicated on the abscissa, and then processed similarly as in the dose-response study for SOD assay of cell extracts. Data represent the means $\pm S E$ of triplicate wells from one experiment.

thine oxidase-induced injury, ${ }^{3-6}$ but no studies have been done using reagent grade $\mathrm{H}_{2} \mathrm{O}_{2}$ or activated neutrophils. In this study, for the first time, resistance to neutrophil or $\mathrm{H}_{2} \mathrm{O}_{2}$-induced injury has been documented in cells that have been preloaded with SOD, suggesting that intracellularly generated $\mathrm{O}_{2}{ }^{-}$plays a significant role in $\mathrm{H}_{2} \mathrm{O}_{2}$-induced endothelial cell injury.

\section{MATERIALS AND METHODS}

\section{Reagents}

Bovine CuZn-SOD was purchased from Sigma Chemical Co. (St. Louis, MO) and Diagnostic Data, Inc. (Mountain View, CA). Although these two preparations had different specific activities, no significant differences were noted in their effects if equivalent doses (in terms of catalytic activity) were used. Bovine serum albumin, ficoll-hypaque (Histopaque), phorbol 12-myristate 13-acetate (PMA), and ( \pm )-epinephrine $\mathrm{HCl}$ were purchased from Sigma Chemical Co. (St. Louis, MO). $\mathrm{Na}\left[{ }^{51} \mathrm{Cr}\right] \mathrm{O}_{4}$ for use in the cytotoxicity assay was obtained from New England Nuclear (Boston, MA). Media and reagents for tissue culture were obtained from sources previously indicated. ${ }^{9}$ All other reagents were of reagent grade or better, unless otherwise specified.

\section{Endothelial cells and SOD loading}

Rat pulmonary artery endothelial cells were isolated, characterized, and maintained as previously described. ${ }^{9-13}$ For SOD loading, cells were plated in 24-well culture plates at a concentration of $2 \times 10^{5}$ cells $/ \mathrm{mL}$ with a final volume of $1 \mathrm{~mL}$, and incubated overnight in minimal essential media with $10 \%$ fetal bovine serum (MEM-10). After washing with serum-free MEM supplemented with $2 \mathrm{mg} / \mathrm{mL}$ bovine serum albumin (MEMBSA), the cells were incubated in this same media containing the indicated concentration of SOD in a final volume of $0.5 \mathrm{~mL}$, and incubated for $18 \mathrm{~h}$, except otherwise indicated in the time course studies. SODloaded cells were washed twice with $1 \mathrm{~mL}$ of MEMBSA to remove unincorporated enzyme. For control studies requiring catalytically inactive $\mathrm{SOD}$, the enzyme was inactivated by treatment with $\mathrm{H}_{2} \mathrm{O}_{2}$ in an alkaline buffer $\left(0.1 \mathrm{M} \mathrm{Na} \mathrm{NO}_{3}, \mathrm{pH} 10.5\right)$ as previously described, ${ }^{14}$ and was used after extensive dialysis against Hank's balanced salt solution.

For analysis of SOD loading or supplementation, the cells were then treated with $0.5 \%$ trypsin for $5 \mathrm{~min}$ at $37^{\circ} \mathrm{C}$ to digest residual SOD which may be bound to the external surface of the cell membrane. After neutralization of the trypsin with MEM-10, the cells were washed with MEM-BSA and extracted with a buffer containing $0.1 \mathrm{M} \mathrm{Na}_{2} \mathrm{CO}_{3}$ (pH 10.2), $0.2 \mathrm{mM}$ EDTA, $0.2 \%$ Triton $\mathrm{X}-100$ and $1 \mathrm{mM}$ phenylmethylsulfonyl fluoride (PMSF). The soluble extracts were then assayed as described below for SOD or catalase activities.

To monitor the stability of the loaded cell-associated SOD, the cells were washed twice with MEM-BSA after loading, and incubated for the indicated time intervals. At the end of incubation the cells were washed, trypsinized, neutralized, and extracted as described above. The 


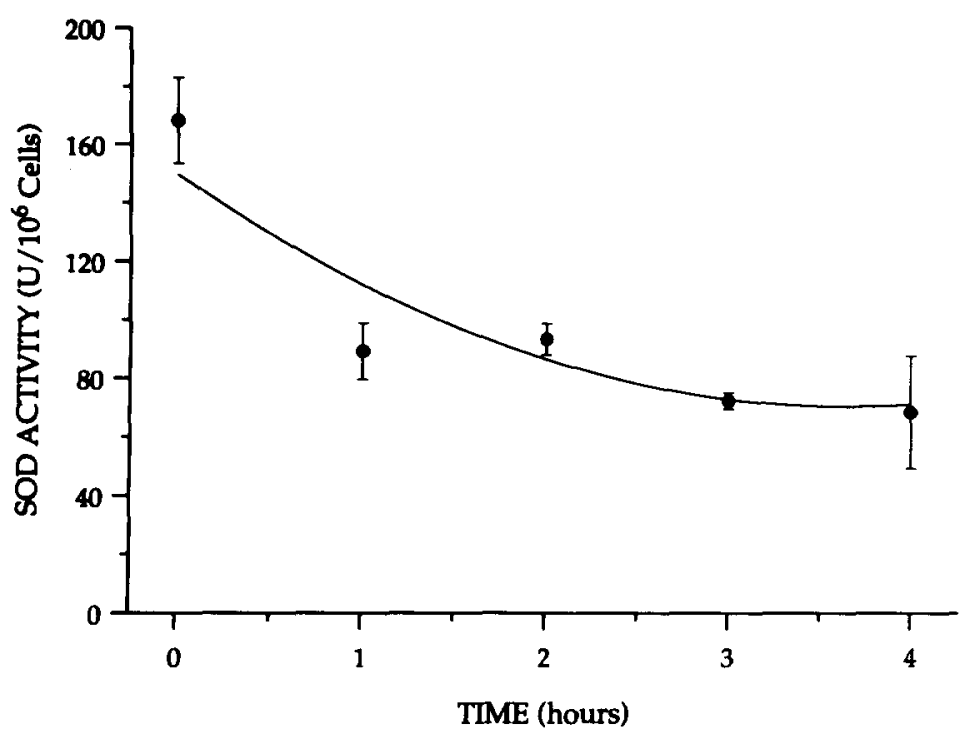

Fig. 2. Stability of exogenous SOD. Endothelial cells were incubated with $10 \mathrm{mg} / \mathrm{mL}$ of SOD for $18 \mathrm{~h}$ and washed to remove excess unincorporated enzyme. They were then incubated for the times indicated on the abscissa before washing, trypsinization, and extraction for SOD assay as described in Methods. Data represent the means $\pm \mathrm{SE}$ with $N=3$.

extracts were then assayed for SOD activity as described below. For cytotoxicity studies, the washed SOD-loaded cells were used directly in the assay without prior trypsinization, as described below.

\section{Cytotoxicity assay}

This assay was performed as previously described using ${ }^{51} \mathrm{Cr}$ release as an index of cell lysis. ${ }^{9}$ Briefly, cells seeded in 24-well culture plates as described above were incubated with the indicated concentrations of SOD and $\mathrm{Na}\left[{ }^{51} \mathrm{Cr}\right] \mathrm{O}_{4}$ for $18 \mathrm{~h}$. The wells were then washed twice with MEM-BSA to remove unincorporated SOD and ${ }^{51} \mathrm{Cr}$. The monolayers were then treated with either the indicated concentration of $\mathrm{H}_{2} \mathrm{O}_{2}$ or neutrophils. In the case of $\mathrm{H}_{2} \mathrm{O}_{2}$-induced cytotoxicity, the cells were incubated for $4 \mathrm{~h}$ at $37^{\circ} \mathrm{C}$ prior to collection of media and cell extract for radioactive counting to arrive at the cytotoxicity index. ${ }^{9}$ In the case of wells receiving neutrophils, after a 30-min incubation to allow the neutrophils to settle onto the monolayer, $100 \mathrm{ng} / \mathrm{mL}$ of PMA was added and the incubation continued for $4 \mathrm{~h}$ at $37^{\circ} \mathrm{C}$. Samples of media and cell extract were then collected for determination of cytotoxicity index as described previously. ${ }^{9,13}$ Control studies have shown that unstimulated neutrophils or PMA alone did not cause significant cytotoxicity. ${ }^{13}$

\section{Enzyme assays}

SOD activity was assayed using the method of Misra and Fridovich, ${ }^{15}$ based on the measurement of inhibition of epinephrine autoxidation to adrenochrome. A unit of activity was defined as the amount of sample causing $50 \%$ inhibition of adrenochrome formation. Cell extraction buffer components were found not to interfere with this assay (data not shown). Using this assay, the mean-specific activities of the SOD preparations used in these experiments were $11,028 \pm 228(N=4)$ and $19,983 \pm 1,173(N=5)$ units/mg for the Sigma and Diagnostic Data enzymes, respectively.

Catalase activity was assayed in cell extracts as well, to determine if any effects due to cellular SOD supplementation could be mediated by increases in intracellular catalase. This was done by monitoring the consumption of $\mathrm{H}_{2} \mathrm{O}_{2}$ at $240 \mathrm{~nm},{ }^{16}$ with activity defined as the change in absorbance per minute at $25^{\circ} \mathrm{C}$ and $\mathrm{pH} 7.0$.

\section{Statistical analysis}

Statistical comparisons between the means of treatment groups were undertaken using analysis of variance, with Scheffe's test for making internal comparisons between any two groups. ${ }^{17}$

\section{RESULTS}

\section{SOD supplementation in endothelial cells}

Previous studies have shown efficient loading of SOD and other enzymes into cells by encapsulation in phospholipid vesicles or the use of polyethylene glycolconjugated enzymes. ${ }^{3-5}$ In this study, an alternative 


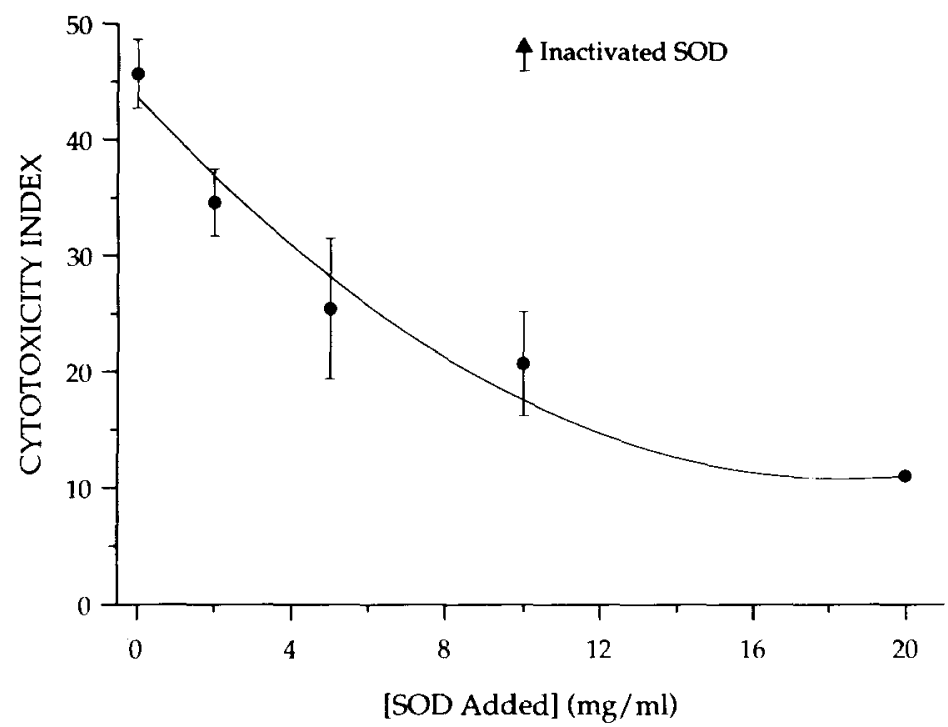

Fig. 3. Effect of SOD supplementation on $\mathrm{H}_{2} \mathrm{O}_{2}$-induced cytotoxicity. Endothelial cells were loaded with ${ }^{51} \mathrm{Cr}$ and the indicated doses of SOD for 18h. After washing, the cells were exposed to $0.1 \mathrm{mM} \mathrm{H}_{2} \mathrm{O}_{2}$ for $4 \mathrm{~h}$, and samples of media and cell extract were counted to determine cytotoxicity index as described in Methods. Data represent the means \pm SE with $N=3$. Only mean values for cells supplemented with 10 and $20 \mathrm{mg} / \mathrm{mL}$ of catalytically active SOD were significantly different $(p<0.05)$ from non+supplemented control value. "Inactivated SOD" refers to cells loaded with $10 \mathrm{mg} / \mathrm{mL}$ SOD which had been inactivated by alkaline $\mathrm{H}_{2} \mathrm{O}_{2}$ treatment as described in Methods.

approach was used to load SOD into endothelial cells with a minimum of perturbation. Rat pulmonary artery endothelial cells were incubated with increasing concentrations of SOD to see if their intracellular levels of this enzyme could be significantly increased to a level sufficient to protect against oxidant-induced cytotoxicity. After an overnight $(18 \mathrm{~h})$ incubation, these cells were found to contain up to as much as $>17$-fold the control or endogenous activity when incubated with 10 $\mathrm{mg} / \mathrm{mL}$ of exogenous SOD (Fig. 1a). The dose-response curve showed a relatively linear rate of uptake until a dose of $5 \mathrm{mg} / \mathrm{mL}$ was reached, at which point the curve appeared to plateau as it approached $10 \mathrm{mg} / \mathrm{mL}$. This activity was resistant to trypsinization of the intact cells during preparation of the cell extracts, suggesting an intracellular location. Identical treatment of cell extracts with trypsin resulted in $62 \%$ inhibition of SOD activity, suggesting that resistance to the trypsinization procedure is suggestive of its intracellular location. When these same cell extracts were analyzed for catalase activity, no significant differences were observed between those from control, nonsupplemented cells versus those from SOD-supplemented cells (data not shown), indicating that there was insignificant contamination of the SOD preparation by catalase, and that SOD supplementation did not cause elevation of endogenous intracellular catalase activity.

The time course for uptake of SOD is shown in Fig. $1 \mathrm{~b}$. When cells were incubated in the presence of 10 $\mathrm{mg} / \mathrm{mL}$ SOD, the rate of increase in cell-associated SOD appeared linear up to $8 \mathrm{~h}$, after which the curve began to plateau. On the basis of this curve, all subsequent loadings were undertaken for 16-18 h. The stability of the exogenous SOD taken up by the cells was also examined. Since all cytotoxicity assays required $4 \mathrm{~h}$ of incubation, the stability study was undertaken from 1-4 $h$ after the end of the 16-18-h period of SOD loading. Figure 2 showed that there was an initial decline during the first hour after the cessation of loading, being reduced to approximately $53 \%$ of the control (time 0 ) level. Subsequently, there was a slow rate of decline, such that at the end of $4 \mathrm{~h}$, about $38 \%$ of the initial enzyme level remained, which was still about six-fold the endogenous level in nonsupplemented cells.

\section{Protective effects of SOD supplementation on $\mathrm{H}_{2} \mathrm{O}_{2}$-induced cytotoxicity}

Previous studies have shown that $\mathrm{H}_{2} \mathrm{O}_{2}$-induced cytotoxicity is associated with increases in ATP degradation products, including hypoxanthine and xanthine. ${ }^{18,19}$ Since rat pulmonary artery endothelial cells contain xanthine oxidase, ${ }^{13}$ which uses these bases as substrates, these findings taken together raise the possibility that $\mathrm{O}_{2}{ }^{-}$derived from xanthine oxidase and other sources may contribute to the killing mechanism. Previous studies have found no significant increase in intracellular xanthine oxidase activity in $\mathrm{H}_{2} \mathrm{O}_{2}$-treated cells, ${ }^{13}$ suggesting that the increase in substrate (i.e., hypoxanthine and xanthine) concentration in these cells may be the determining factor in causing increased $\mathrm{O}_{2}{ }^{-}$production. In order to test this hypothesis, cells were incu- 
bated with increasing doses of SOD to supplement their endogenous levels, and then tested for their susceptibility to $\mathrm{H}_{2} \mathrm{O}_{2}$-induced killing. The results in Fig. 3 reveal an increased resistance (reduced susceptibility to killing) to $0.1 \mathrm{mM} \mathrm{H} \mathrm{H}_{2} \mathrm{O}_{2}$, in proportion to increased loading doses of SOD, such that at a dose of $20 \mathrm{mg} / \mathrm{mL}$ of SOD, the cytotoxicity index was reduced to less than a fourth of the cytotoxicity obtained in cells that had not been supplemented with SOD. Complete protection (100\% inhibition of cytotoxicity) was never accomplished, even at the highest dose of SOD used $(20 \mathrm{mg} / \mathrm{mL})$. The inhibition of cell killing was statistically significant at doses of SOD supplementation $\geq 10 \mathrm{mg} / \mathrm{mL}$, although the magnitude of protection afforded by lower SOD doses was still substantial at $>20 \%$. When cells were incubated with catalytically inactive SOD at a dose of 10 $\mathrm{mg} / \mathrm{mL}$, no significant protection was observed (Fig. 3). If endothelial cells were incubated for only $5 \mathrm{~min}$ with $10 \mathrm{mg} / \mathrm{mL}$ of SOD and washed rapidly, no protection was observed (data not shown). These results suggest that only catalytically active SOD that is intracellular is able to inhibit $\mathrm{H}_{2} \mathrm{O}_{2}$-induced cytotoxicity. That this protection was dependent on the extent of SOD supplementation was brought out more clearly when cytotoxicity index or the degree of protection was plotted against actual cell-associated SOD activity (as a result of the increasing SOD loading dose as shown in Fig. 3) in Fig. 4. Protection appeared to be linearly related to the amount of enzyme activity up to about 60 units $/ 10^{6}$ cells, with the curve reaching a plateau beyond this point. This suggests that increasing the endogenous SOD activity beyond six-fold does not significantly provide additional protection.

When the dose of $\mathrm{H}_{2} \mathrm{O}_{2}$ was increased above 0.1 $\mathrm{mM}$, substantially less protection by $10 \mathrm{mg} / \mathrm{mL}$ SOD supplementation was observed (Fig. 5). Although protection was still apparent at $0.2 \mathrm{mM} \mathrm{H}_{2} \mathrm{O}_{2}$, the magnitude was only less than $30 \%$. At $0.5 \mathrm{mM} \mathrm{H}_{2} \mathrm{O}_{2}$, essentially no protection was observed. These results suggest that intracellular SOD supplementation can protect against $\mathrm{H}_{2} \mathrm{O}_{2}$-induced cytotoxicity, while at higher doses of $\mathrm{H}_{2} \mathrm{O}_{2}$, most of the killing is mediated by mechanisms which are not dependent on the generation of $\mathrm{O}_{2}{ }^{-}$. Alternatively, higher doses of $\mathrm{H}_{2} \mathrm{O}_{2}$ may lead to inactivation of cell-associated SOD.

Protective effects of SOD supplementation on neutrophil-induced cytotoxicity

Neutrophil-induced cytotoxicity in rat pulmonary artery endothelial cells is associated with increased xanthine oxidase activity in the endothelial cells, and inhibitors of xanthine oxidase protect against this type of cytotoxicity. ${ }^{13}$ These findings suggest a possible role for

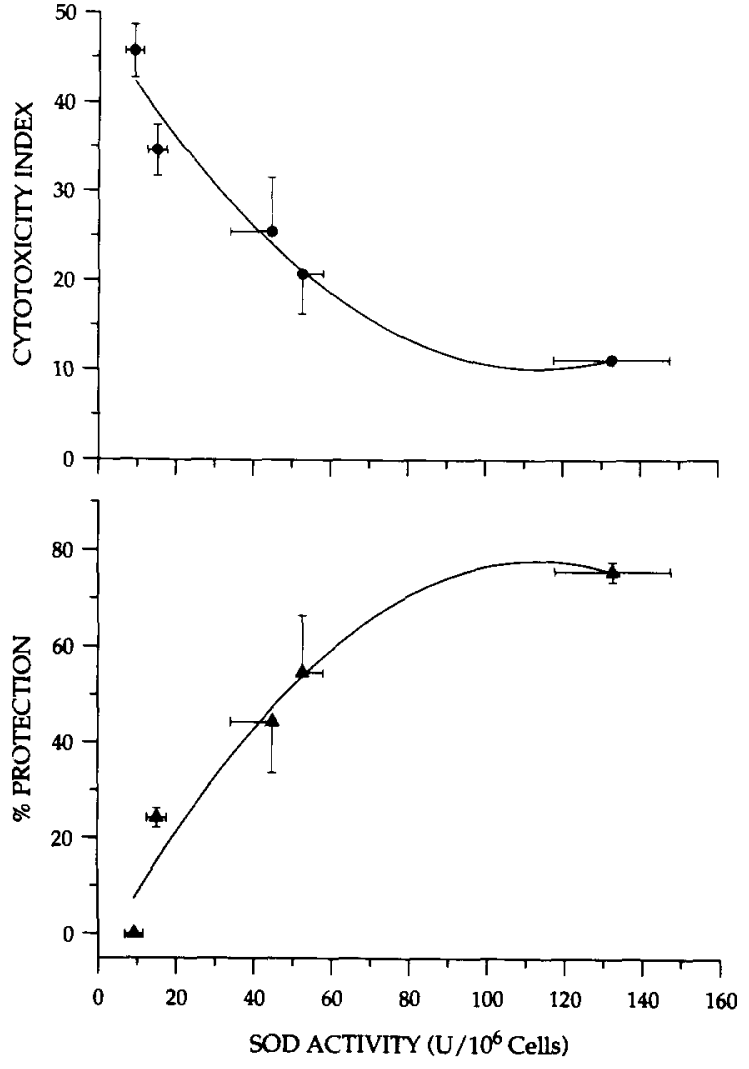

Fig. 4. Protection from $\mathrm{H}_{2} \mathrm{O}_{2}$-induced cytotoxicity by SOD. Data from the experiment described in Fig. 3 were expressed in terms of cytotoxicity index (upper panel) or \% protection (lower panel) versus cell-associated SOD activity in control and SOD-supplemented cells.

$\mathrm{O}_{2}{ }^{-}$generated by xanthine oxidase in the killing process. This hypothesis was tested by supplementing the endothelial cells with SOD prior to exposure to PMAstimulated neutrophils. Figure 6 (upper panel) shows that SOD supplementation partially inhibits neutrophilinduced cytotoxicity over a range of concentration of neutrophils. The inhibition was statistically significant at all neutrophil doses tested, except for the lowest. Although the percent protection was greatest at the lowest dose of neutrophils tested, the reduction in cytotoxicity index was the smallest in terms of absolute value. The magnitude of protection declined with increasing doses of neutrophils, reaching a plateau at slightly $>20 \%$ protection at doses of neutrophils $>1.2$ $\times 10^{6} / \mathrm{mL}$ (Fig. 6, lower panel), or $>6: 1$ ratios of neutrophils to endothelial cells. As was also the case with $\mathrm{H}_{2} \mathrm{O}_{2}$-induced cytotoxicity, intracellular $\mathrm{O}_{2}{ }^{-}$plays a role in cytotoxicity caused by endothelial cell exposure to activated neutrophils.

\section{DISCUSSION}

The primary rationale for this study was to seek additional evidence for the role of intracellular $\mathrm{O}_{2}{ }^{-}$in 


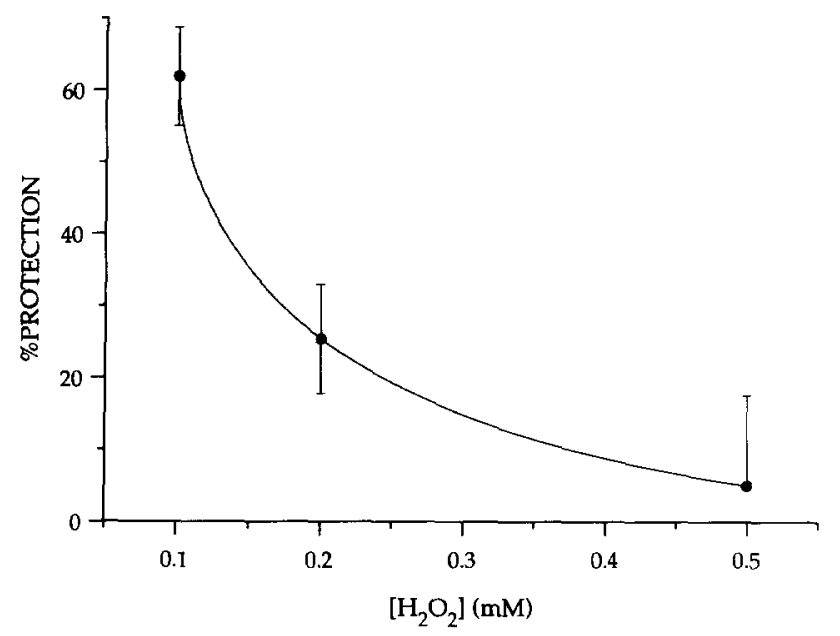

Fig. 5. Effect of $\mathrm{H}_{2} \mathrm{O}_{2}$ dose on protection by SOD. Cells were loaded with $10 \mathrm{mg} / \mathrm{mL}$, SOD and examined for percent protection from cytotoxicity by the indicated doses $\mathrm{H}_{2} \mathrm{O}_{2}$. Data represent the means $\pm \mathrm{SE}$ with $\mathrm{Ns}=5,4$, and 3 for $0.1,0.2$, and $0.5 \mathrm{mM} \mathrm{H}_{2} \mathrm{O}_{2}$, respectively.

$\mathrm{H}_{2} \mathrm{O}_{2}$ and neutrophil-induced cytotoxicity of endothelial cells. There is indirect evidence from studies using certain enzyme inhibitors that $\mathrm{O}_{2}^{-}$, perhaps generated by xanthine oxidase, may be involved in these models of cell injury. ${ }^{13}$ A direct test of this possibility would be to introduce a specific $\mathrm{O}_{2}{ }^{-}$scavenger into target cells and determine if such a treatment could protect the cells from oxidant-induced killing. In order to accomplish this, a method was selected that would cause minimal perturbation of the endothelial cells. Although several methods for introducing enzymes into cells have been reported, these have relied on approaches using either phospholipid vesicles or conjugation of the enzymes with polyethylene glycol. ${ }^{3-5}$ The former results in alterations in membrane phospholipid composition, while the latter causes physical disruption in the integrity of the cell membrane. ${ }^{5}$ In order to avoid these potential problems, a simpler and more reproducible procedure was developed to supplement endothelial cells with exogenous unmodified SOD. Incubation of cells with up to $20 \mathrm{mg} / \mathrm{mL}$ of exogenous SOD results in up to as high as $>17$-fold elevation in cell-associated SOD activity, after only as brief as $8 \mathrm{~h}$ of incubation. A significant portion of the incorporated SOD appears relatively stable over the 4-h period of the cytotoxicity assay. The mechanism of SOD uptake remains to be determined, although previous studies using other macromolecules suggest endocytosis (perhaps, receptor-mediated) is likely to be involved. ${ }^{20-23}$

When supplemented with exogenous SOD in this manner, endothelial cells became more resistant to killing by both $\mathrm{H}_{2} \mathrm{O}_{2}$ and activated neutrophils. The degree of protection afforded was dependent on the loading dose of SOD or the level of cell-associated SOD supplementation, as well as the dose of $\mathrm{H}_{2} \mathrm{O}_{2}$ or neutro- phils. Although complete (100\%) protection was never accomplished by SOD supplementation, protection was substantial at doses of $\mathrm{H}_{2} \mathrm{O}_{2}<0.5 \mathrm{mM}$ or doses of neutrophils $\leq 10: 1$ (neutrophil:endothelial cell ratio). Protection was dependent on catalytic activity of the added SOD. SOD supplementation has to be cellassociated to afford protection as suggested by the following, (i) resistance of the supplemented SOD to trypsinization in the intact cell, and (ii) the absence of protection by brief SOD incubation (insufficient time to load the cell) or extracellular SOD supplementation. ${ }^{24-26}$ However, the relative resistance of bovine $\mathrm{Cu}, \mathrm{Zn}-\mathrm{SOD}$ to proteolysis, and the incomplete inhibition of SOD activity even in lysed cell extracts by trypsinization, made it impossible to completely rule out the possibility of some contribution by cell surface associated SOD in the observed activity in cell extracts. Partial inhibition of SOD activity in cell extracts by trypsinization cannot be totally due to digestion of endogenous MnSOD, since total endogenous SOD activity constituted typically less than $20 \%$ of the total in exogenously supplemented cells while trypsinization of cell extracts actually caused > $60 \%$ inhibition of total cell extract activity. Nevertheless this contribution by cell surface bound SOD is likely to be minor since significant protection was not afforded by brief incubation with identical doses of SOD, which would be expected to cause similar amount of cell surface nonspecific binding but minimal intracellular loading. Although the SOD itself may be relatively resistant to trypsin digestion, most of the cell surface proteins to which it may be bound are not expected to be quite this resistant. Thus trypsinization of the cells would be expected to reduce cell surface binding of the SOD. Thus, despite the fact that unequivocal proof of exclusive intracellular location of the supplemented SOD 

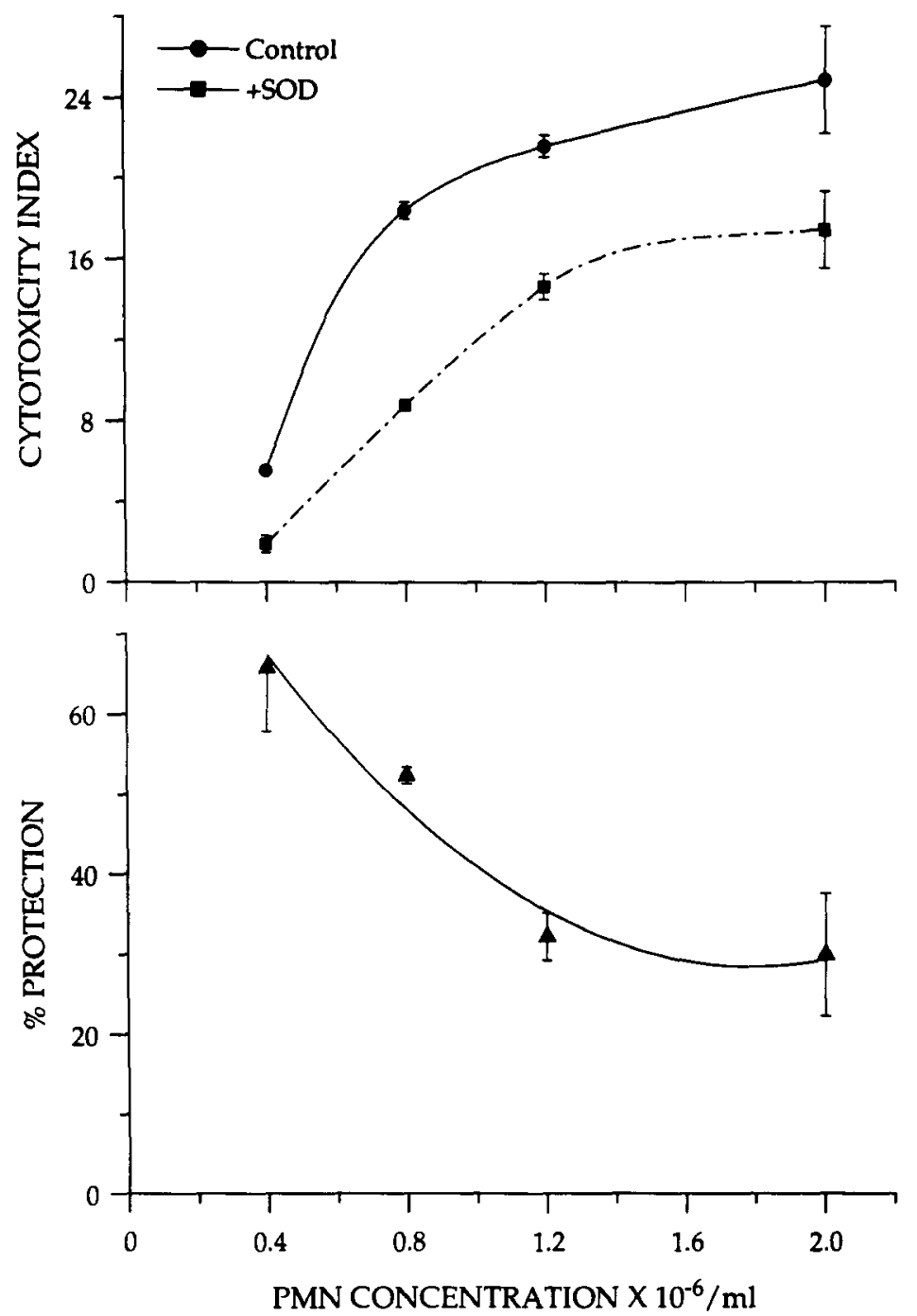

Fig. 6. Protection from neutrophil-induced cytotoxicity by SOD. Endothelial cells were preloaded with SOD and ${ }^{51} \mathrm{Cr}$ as described in the legend to Fig. 3, and then treated with the indicated doses of PMA-stimulated neutrophils (PMN). Each well contained $2 \times 10^{5}$ endothelial cells. All data points represent the means \pm SE with $N=3$. "Control" in the upper panel refers to values from endothelial cells not supplemented with exogenous SOD. All the mean cytotoxicity indices (upper panel) of cells supplemented with SOD were significantly different $(p<0.05)$ from those of nonsupplemented cells at each neutrophil dose, except for the lowest.

is lacking, there is sufficient circumstantial evidence to suggest that the observed protection by SOD supplementation is due to cell-associated enzyme that is not merely loosely bound to the cell surface. Definitive cellular, especially intracellular (organellar vs cytosolic) localization is beyond the scope of these studies, and would require a combination of immunohistochemical and cellular fractionation studies.

Although previous studies have also shown protection by intracellular SOD supplementation using alternative approaches, none have used reagent grade $\mathrm{H}_{2} \mathrm{O}_{2}$ or activated neutrophils as the injurious stimulus. As a matter of fact the protection afforded in response to $\mathrm{H}_{2} \mathrm{O}_{2}$-induced injury was surprising since it has been the accepted but untested assumption that $\mathrm{H}_{2} \mathrm{O}_{2}$ kills by direct oxidation of susceptible cellular targets without mediation by $\mathrm{O}_{2}{ }^{-}$generation. The results thus provide support for the conclusion that intracellular $\mathrm{O}_{2}^{-}$(in the target cell) plays a significant role in endothelial cell cytotoxicity induced by these two agents. The data however did not identify the source of intracellular $\mathrm{O}_{2}{ }^{-}$ in these two models of injury, although xanthine oxidase is a likely source based on previous inhibitor studies. ${ }^{13}$ There is precedent for a role for intracellular $\mathrm{O}_{2}{ }^{-}$in $\mathrm{H}_{2} \mathrm{O}_{2}$-induced cytotoxicity in microbial systems. ${ }^{27,28}$

These data add to the growing body of evidence that the killing of endothelial cells either by $\mathrm{H}_{2} \mathrm{O}_{2}$ or activated neutrophils is mediated by $\mathrm{O}_{2}{ }^{-}$. Although neutrophil-generated $\mathrm{O}_{2}{ }^{-}$may enter the endothelial cell via anion channels, in the case of $\mathrm{H}_{2} \mathrm{O}_{2}$-mediated cytotox- 
icity, a role for $\mathrm{O}_{2}{ }^{-}$exogenous to the endothelial cell can be ruled out. It appears reasonable to speculate that the role of intracellularly generated $\mathrm{O}_{2}{ }^{-}$may be to bring about reduction of $\mathrm{Fe}^{3+}$ to $\mathrm{Fe}^{2+}$ which can then interact with $\mathrm{H}_{2} \mathrm{O}_{2}$ diffusing into the endothelial cell, the end result being formation of the highly reactive hydroxyl radical. This speculation is consistent with the earlier observation showing that pretreatment of endothelial cells with deferroxamine is highly protective against cytotoxicity caused by activated neutrophils. ${ }^{9}$ Although the source of $\mathrm{O}_{2}{ }^{-}$in the endothelial cells is not directly demonstrated, the possibility of xanthine oxidase being the source is compatible with the observation that allopurinol, oxypurinol, and lodoxamide are protective against neutrophil-associated cytotoxicity, perhaps because of their ability to limit the amount of substrate available for xanthine oxidase. Obviously, the contribution of mitochondria, cyclooxygenase, and other enzymes in the endothelial cell to the intracellular formation of $\mathrm{O}_{2}^{-}$cannot be excluded.

Acknowledgements - This work was supported by National Institutes of Health grants HL28737, HL31963, HL39925, HL07517, DK38149, GM28499, GM29507, and American Cancer Society grant IM-432 (University of Michigan); and National Institutes of Health grants HL21568 and HL33064 (University of Miami). Part of this work was performed during the tenure of an Established Investigatorship (SHP) from the American Heart Association.

\section{REFERENCES}

1. Freeman, B.A.; Jackson, R.M.; Matalon, S.; Harding, S.M. Biochemical and functional aspects of oxygen-mediated injury to vascular endothelium. In: Ryan, U.S., ed. Endothelial cells, Vol. III. Boca Raton, FL: CRC Press; 1988:13-32.

2. Rosen, G.M.; Freeman, B.A. Detection of superoxide generated by endothelial cells. Proc. Natl. Acad. Sci. USA 23:7269-7273; 1984.

3. Freeman, B.A.; Young, S.L.; Crapo, J.D. Liposome-mediated augmentation of superoxide dismutase in endothelial cells prevents oxygen injury. J. Biol. Chem. 258:12534-12542; 1983.

4. Beckman, J.S.; Minor, R.L. Jr; Freeman, B.A. Augmentation of antioxidant enzymes in vascular endothelium. Free Radic. Biol. Med. 2:359-365; 1986.

5. Beckman, J.S.; Minor, R.L. Jr; White, C.W.; Repine, J.E.; Rosen, G.M.; Freeman, B.A. Superoxide dismutase and catalase conjugated to polyethylene glycol increases endothelial enzyme activity and oxidant resistance. J. Biol. Chem. 263:6884-6892; 1988

6. Freeman, B.A.; Turrens, J.F.; Mirza, Z.; Crapo, J.D.; Young, S.L. Modulation of lung injury by using liposome-entrapped superoxide dismutase and catalase. Fed. Proc. 44:2591-2595; 1985.

7. Tanswell, A.K.; Freeman, B.A. Liposome-entrapped antioxidant enzymes prevent lethal $\mathrm{O}_{2}$ toxicity in the newborn rat. Am. J. Physiol. 63:347-352; 1987.

8. Ryan, U.S. Phagocytic properties of endothelial cells. In: Ryan, U.S., ed. Endothelial cells, Vol. III. Boca Raton, FL: CRC Press; 1988:33-52.
9. Gannon, D.E.; Varani, J.; Phan, S.H.; Ward, J.H.; Kaplan, J.; Till, G.O.; Simon, R.H.; Ryan, U.S.; Ward, P.A. Source of iron in neutrophil-mediated killing of endothelial cells. Lab. Invest. 57:37-44; 1987.

10. Ryan, U.S. Isolation and culture of pulmonary endothelial cells. Env. Health Perspect. 56:103-114; 1984.

11. Ryan, U.S.; White, L.; Lopez, M.; Ryan, J.W. Use of microcarriers to isolate and culture pulmonary microvascular endothelium. Tissue Cell 14:597-560; 1982.

12. Ryan, U.S.; White, L. Microvascular endothelium isolation with microcarriers: arterial, venous. J. Tissue Cult. Methods 10:9-13; 1986.

13. Phan, S.H.; Gannon, D.E.; Varani, J.; Ryan, U.S.; Ward, P.A. Xanthine oxidase activity in rat pulmonary artery endothelial cells and its alteration by activated neutrophils. Am, J. Pathol. 134: 1201-1211; 1989.

14. Hodgson, E.K.; Fridovich, I. The interaction of bovine erythrocyte superoxide dismutase with hydrogen peroxide: inactivation of the enzyme. Biochemistry 14:5294-5299; 1975.

15. Misra, H.P.; Fridovich, I. The role of superoxide anion in the autoxidation of epinephrine and a simple assay for superoxide dismutase. J. Biol. Chem. 247:3170-3175; 1972.

16. Beers, R.F. Jr; Sizer, I.W. A spectrophotometric method for measuring the breakdown of hydrogen peroxide by catalase. $J$. Biol. Chem. 195:133-140; 1952.

17. Scheffé, H. The analysis of variance. New York: J Wiley \& Sons; 1959.

18. Spragg, R.G.; Hinshaw, D.B.; Hyslop, P.A.; Schraufstatter, I.U.; Cochrane, C.G. Alterations in adenosine triphosphate and energy charge in cultured endothelial and $\mathrm{P}_{388 \mathrm{D}_{1}}$ cells after oxidant injury. J. Clin. Invest. 76:1471-1476; 1985.

19. Hyslop, P.A.; Hinshaw, D.B.; Halsey, W.A.; Schraufstetter, I.U.; Jackson, J.H.; Spragg, R.A.; Sauerheber, R.D.; Cochrane, C.G. Mechanisms of oxidant mediated cell killing: the glycolitic and mitochondrial pathways of ADP phosphorylation are major targets of $\mathrm{H}_{2} \mathrm{O}_{2}$-mediated injury. J. Biol. Chem. 263:1665-1675; 1988.

20. Williams, S.K.; Greener, D.A.; Solenski, N.J. Endocytosis and exocytosis of protein in capillary endothelium. J. Cell. Physiol. 120: $157-168 ; 1984$.

21. Davies, P.F.; Dewey, C.F. Jr; Bussolari, S.R.; Gordon, E.J.; Gimbrone, M.A. Influence of hemodynamic forces on vascular endothelial function. J. Clin. Invest. 73:1121-1130; 1984.

22. Soda, R.; Tavassoli, M.; Jacobsen, D.W. Receptor distribution and the endothelial uptake of transcobalamin II in the liver cell suspensions. Blood 65:795-802; 1985.

23. Tavassoli, M.; Kishimoto, T.; Kataoka, M. Liver endothelium mediates the hepatocytes' uptake of ceruloplasmin. J. Cell Biol. 102:1298-1309; 1986.

24. Weiss, S.J.; Young, J.; LoBuglio, A.F.; Slivka, A.; Nimeh, N.F. Role of hydrogen peroxide in neutrophil-mediated destruction of cultured endothelial cells. J. Clin. Invest. 68:714-718; 1981.

25. Martin, W.J. Neutrophils kill pulmonary endothelial cells by a hydrogen peroxide-dependent pathway. An in vitro model of neutrophil-mediated lung injury. Am. Rev. Resp. Dis. 130:209$214 ; 1984$

26. Varani, J.; Fliegel, S.E.G.; Till, G.O.; Kunkel, R.G.; Ryan, U.S.; Ward, P.A. Pulmonary endothelial cell killing by human neutrophils: possible involvement of hydroxyl radical. Lab. Invest. 53:656-663; 1985.

27. Carlioz, A.; Touati, D. Isolation of superoxide dismutase mutants in Escherichia coli: is superoxide dismutase necessary for aerobic life? EMBO J. 5:623-630; 1986.

28. Cantoni, O.; Brandi, G.; Schiavano, G.F.; Albano, A.; Cattabeni, F. Lethality of hydrogen peroxide in wild type and superoxide dismutase mutants of Escherichia coli. (A hypothesis on the mechanism of $\mathrm{H}_{2} \mathrm{O}_{2}$-induced inactivation of Escherichia coli). Chem. Biol. Interact. 70:281-288; 1989 